Revue bibliographique pour le domaine irano-aryen

\title{
Rüdiger Schmitt (with contributions of Hamid Rezai Sadr). "A New Inscription of Xerxes? One More Forgery"
}

\section{Rémy Boucharlat}

\section{(2) OpenEdition Journals}

Édition électronique

URL : http://journals.openedition.org/abstractairanica/47330

DOI : 10.4000/abstractairanica.47330

ISBN : 1961-960X

ISSN : 1961-960X

Éditeur :

CNRS (UMR 7528 Mondes iraniens et indiens), Éditions de l'IFRI

\section{Référence électronique}

Rémy Boucharlat, «Rüdiger Schmitt (with contributions of Hamid Rezai Sadr). "A New Inscription of Xerxes? One More Forgery" », Abstracta Iranica [En ligne], Volume 37-38-39 | 2018, document 97, mis en ligne le 30 décembre 2018, consulté le 02 octobre 2020. URL : http://journals.openedition.org/ abstractairanica/47330 ; DOI : https://doi.org/10.4000/abstractairanica.47330

Ce document a été généré automatiquement le 2 octobre 2020.

Tous droits réservés 


\title{
Rüdiger Schmitt (with contributions of Hamid Rezai Sadr). "A New Inscription of Xerxes? One More Forgery"
}

\author{
Rémy Boucharlat
}

\section{RÉFÉRENCE}

Rüdiger Schmitt (with contributions of Hamid Rezai Sadr). "A New Inscription of Xerxes? One More Forgery”, Arta 2015.003, 8 p. http://www.achemenet.com/pdf/arta/ ARTA_2015.003-Schmitt.pdf

1 Le texte d'une inscription sur table en pierre saisie par la police de province d'Azerbaïdjan oriental se rapprocherait de l'inscription de Xerxès à Van (XV). Le faussaire n'était cependant pas assez compétent en vieux-perse pour éviter nombre de fautes de grammaire et, plus grave, d'avoir omis l'indispensable "Moi "en tête de la formule "qu'Ahura Mazda me protège". De plus, le texte est gravé de droite à gauche, ce qui est presque unique dans les inscriptions royales achéménides.

\section{AUTEURS}

RÉMY BOUCHARLAT

UMR 5133 CNRS-Université de Lyon 